\title{
Parental factors and their effects on students' learning in Mathematics
}

\section{Yam Prasad Pandaya}

\begin{abstract}
Children's academic achievement and educational attainment have been studied within different frameworks. This study has focused on parents' education, occupation, and economic status. The objective of this study was to measure effect of parental qualification, occupation, and economic status and mathematical achievement of children in Sindhuli District, Nepal. The design of the study was survey and method of study was quantitative The population of this research was of $9^{\text {th }}$ grade students of Sindhuli District. The sample consists of 90 students of 9 th grade in Kamalamai Municipality, Sindhuli. Both primary and secondary data was used to draw the conclusion of this research. Questionnaire was tool for primary data collection and school records were used as secondary data of this study. To test the significance Chi-square statistical tool was used at 5\% level of significance. Conclusion based on the finding of this study was that there is significance relationship between parental qualification, profession, economic status and mathematical achievement of their children. This study will be one of the reference materials in the field for learners and its stakeholders. Specifically the teacher can use the result of this study during teaching in the classroom.
\end{abstract}

Keywords: Parental, Mathematics, achievement, qualification, occupation

\section{Introduction}

The importance of mathematics to an individual and society is clearly beyond debate. Mathematics is the necessity of the civilization. Thus, every individual needs some knowledge in order to live a useful life and be an effective member of society. Pandit (1994, P. 17) clarifies the importance of mathematics as; i) Mathematics as a tool for an efficient citizen and livelihood, ii) Mathematics as a tool for the functioning of the technological world, and iii) Mathematics as the right that every citizen deserves.

Despite the irrefutable significance of mathematics in the school curriculum, academically capable students prematurely restrict their educational and career options by discontinuing their mathematical learning early in the high school. The poor result in this subject has continued to be stumbling-blocks in the realisation of the educational and employment desire of many candidate because it is a gatekeeper for many careers. The mathematics achievement of students effect different factors like; socio-economic status, qualification, support and involvement of parents. Acharya,(2017, P. 13) said" those parents who have good economic condition, most of their children's education is good because they can manage tutor at home as much as possible. But 
these conditions we cannot find in poor family". This shows that good economic condition is helpful for better performance in mathematics.

Many researchers show parental involvement play very important role on children's academic achievement in mathematics. The parental involvement on their children study is affected by their occupation and qualification. According to Grissmer (2003, P.120), parent's level of education is the most important factor affecting students' academic achievement. Similarly, Taiwo (1993, P.107), submits that "parents educational background influence the academic achievement of students because the parents would be in the good position to be the second teachers to the child; even guide and counsel the child on the best way to perform well in the education and provide the necessary materials needed by him/her". This was supported by Musgrave (2000, P.383) who said, "parents who have more than minimum level of education are expected to have a favoured attitude to the child education and to encourage and help him/her with school work." The educated family know the importance of mathematics so they provide various facilities to encourage the child.

According to Ahmad \& Najeemah (2013, P.1), "Students' academic achievement and educational attainment have been studied within different frameworks. Many of them have a focus on parents' education, occupation or home background, while other studies looked at it from the teachers' variables, school variable students' variables".

Schunk, Pintrich and Meece (2008, p.112) affirmed, " there is a consistent finding of motivation being related to achievement behaviours. The impact of motivation on learning of mathematics by a child cannot be undermined". Hall (1989) believes that there is a need to motivate students so as to arose and sustain their interest in learning mathematics. He further opines that mathematics' academic achievement should be considered a continuous process until there is evidence of improvement in interest and performance of the learners in the subject.

The greater involvement of parents results in development of positive attitudes of children toward school, classes, and enhancement of academic achievement (Stevenson and Baker, 1987). It is believed that low socio-economic status negatively influences academic achievement, in part, because it prevents students from accessing various educational materials and resources, and creates a distressing atmosphere at home (Jeynes, 2002). For these reasons, socioeconomic status of a parent is a common factor that determines academic achievement children.

Educators have relied on many sources of information and focused on various factors that might affect students' mathematical achievements, including students' own backgrounds, peer environment, and parental involvement (Young, Reynolds \& Walberg, 1996). This study show that mathematical achievement of students is depends on the qualification, occupation/profession and economic status of family. The students from poor family themselves consider inferior and 
think that their parents cannot afford for higher study. As a consequence, they are not serious in study.

There is gap be between the expectation of parents, teachers, school management, and other stockholders of education business and mathematical achievement of children. In the present context of education at high school, the achievement of students in mathematics is not satisfactory. Educationists as well as state are facing the challenges with the problems of failure in SLC/SEE examination in mathematics. They want to minimize this problem but the problem is increasing every day. All the students irrespective of gender, age, class and creed feel that solving mathematical problem is a tough task they face every day in their classrooms. Students' attitude towards the subject, socio- economic condition of country, school environment, family back ground, subject teacher, and parents' academic qualification, occupation, and their involvement and motivation are main cases behind this. The main purpose of the study is to find the status of parental qualification, occupation and economy and their effect in mathematical achievement of children.

Many researches had been carried out and articles have been published in this area addressing the better achievement of children in mathematics. But the researcher of this study has tried to include parental factors such as academic qualification, occupation together with economic status for better performance in mathematics. As time elapsed, the political, economic, social, geographical, religious and educational conditions have been changed. The attitude of student, parent and teacher has also been changed. So the knowledge once attain does not remain applicable forever. The researcher believes that this study help to add new knowledge in education field in the present context of Nepal. This study will be one of the reference material for learners and its stakeholders. Specifically the teacher can use the result of this study during teaching in the classroom. If the teacher knows the family environment then he can choose teaching strategies accordingly. Similarly, the guardians and parents can be benefited by it because home is first school of the children and they can learn many things from their parents.

\section{Methodology}

The design of the study was quantitative and the method of study was survey. The population of this research was of 9th grade students of Sindhuli District in academic year 2076. The sample consists of 90 students of 9th grade in Kamalamai Municipality, Sindhuli. The researcher selected three private and three government-aided schools following purposive sampling from Kamalamai municipality, Sindhuli. After selection of schools, fifteen students of 9 th grade had been selected randomly from each school. There were 90 students in sample including 15 students from each six schools.

This study has been based on primary as well as secondary data. School records of 
students were considered as secondary data. From the school record the achievement of students in mathematics has been taken. The achievement of students in this study is regarded as the display of knowledge attained or skills, shown in the math subject such achievements are indicated by test scores or by marks assigned by teachers. It is the school evaluation of students' classroom work as quantified on the basis of marks or grades. For reliability, the marks obtained by class 8 in district level exam have been brought into use.

The achievements of students have been utilized as base line data against which parents' occupation, qualification, and economic status has been analyzed as main variables on this study. Information about Parents' occupation, qualification, and economic status were collected from primary data. Questionnaire was tool of primary data collection. All information gathered from both primary and secondary sources has been processed, analyzed and interpreted as quantitative one. To find the relationship between children achievement in mathematics and parents' qualification, occupation, and economic status, the tabulation, diagrammatic representation and descriptive method were used. To test significance Chi-square test at 5\% level of significance has been used.

\section{Results and Discussion}

\section{Students' Achievement in Mathematics}

The grade point of the respondents has been presented in the following table:

Table 1. Students Achievement in Mathematics

\begin{tabular}{|c|c|c|c|}
\hline S.N. & Grade & No. of Students & Percentage (\%) \\
\hline 1 & $\mathrm{~A}^{+}$ & 24 & 26.67 \\
\hline 2 & $\mathrm{~A}$ & 12 & 13.33 \\
\hline 3 & $\mathrm{~B}^{+}$ & 7 & 7.78 \\
\hline 4 & $\mathrm{~B}$ & 5 & 5.56 \\
\hline 5 & $\mathrm{C}^{+}$ & 7 & 7.78 \\
\hline 6 & $\mathrm{C}$ & 10 & 11.11 \\
\hline 7 & $\mathrm{D}^{+}$ & 21 & 23.33 \\
\hline 8 & $\mathrm{D}$ & 1 & 1.00 \\
\hline 9 & $\mathrm{E}$ & 3 & 3.33 \\
\hline & Total & 90 & $100 \%$ \\
\hline
\end{tabular}

Table 1 shows that out of 90 respondents, 24(26.67\%) students obtained the grade $\mathrm{A}^{+}$, $12(13.33 \%)$ students obtained A, 7(7.78\%) students obtained $\mathrm{B}^{+}$and $5(5.56 \%)$ students obtained B grade. Similarly $10(11.11 \%)$ students obtained C, 21 students obtained $\mathrm{D}^{+}, 1(1.00 \%)$ student obtained D grade and $3(3.33 \%)$ students have got E grade. This result shows that many students have got low grade thus we conclude that achievement of students in mathematics is not satisfactory. 


\section{Academic Qualification of the Parents}

Academic qualification of the parents of selected students has been presented below:

Table 2. Academic Qualification of the Parents

\begin{tabular}{|c|l|c|c|}
\hline S.N. & \multicolumn{1}{|c|}{ Academic Qualifications } & Number of Parents & Remarks \\
\hline 1 & Below SLC/SEE & 46 & \\
\hline 2 & SLC/SEE passed & 26 & \\
\hline 3 & 12 class passed & 8 & \\
\hline 4 & Bachelor and above & 10 & \\
\hline \multicolumn{2}{r|}{ Total } & 90 & \\
\hline
\end{tabular}

Table 2 shows that most of the parents have their academic qualification below SLC/ SEE. In number, out of 90, 46 haven't pass SLC/SEE level, 26 passed SLC/SEE level only, 8 have passed 12 class and 10 have their qualification bachelor degree or master degree. Thus it can be said that academic qualifications of the parents were very low.

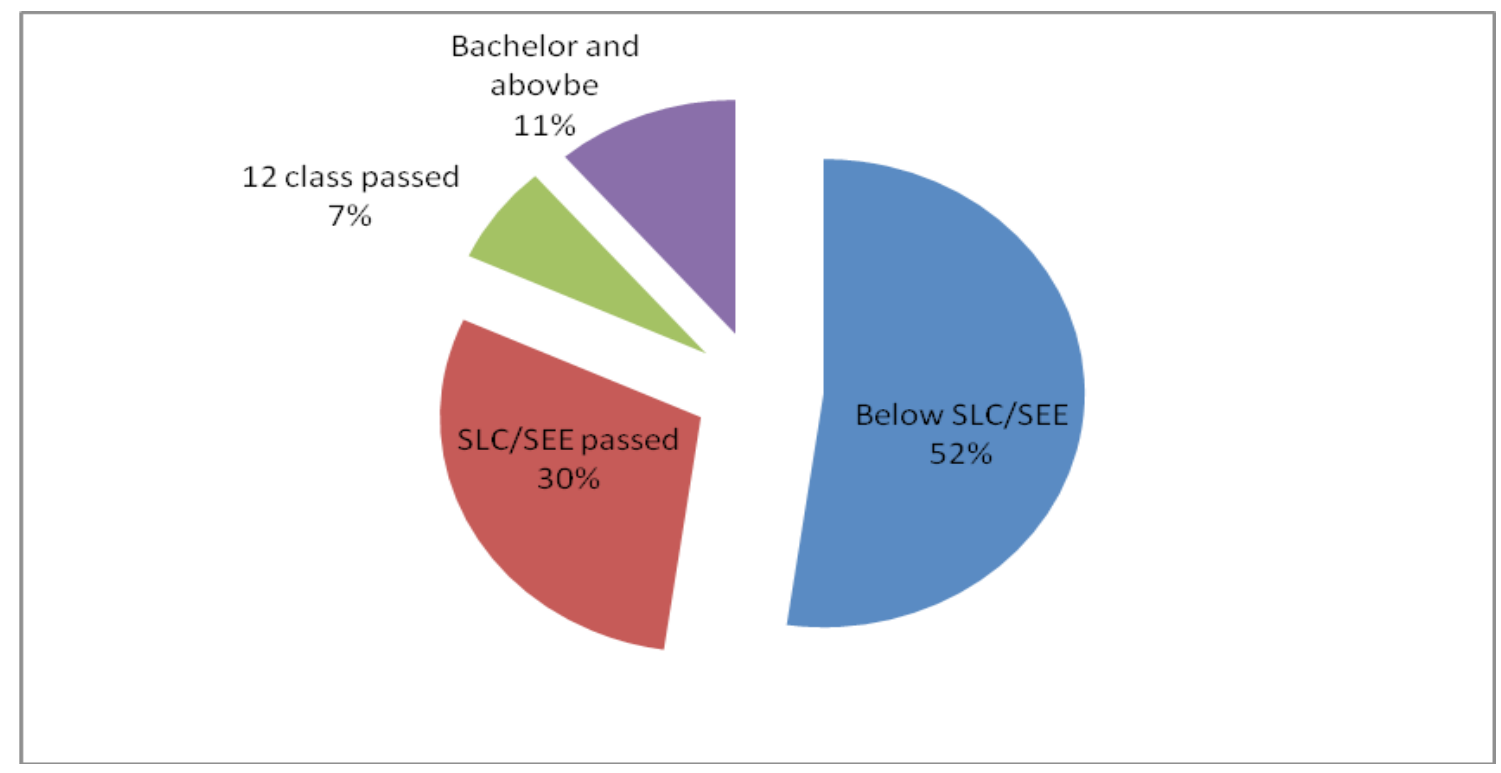

Figure 1. Academic Qualification of the Parents

Figure 1 shows that 52\% parents have their qualifications below SLC/SEE, 30\% parents have passed SLC/SEE, 7\% passed class 12, and 11\% have bachelor or master degree.

\section{Grade of students whose parents have qualification below SLC/SEE}

The achievements of students whose parents have qualification SLC/SEE have been presented in the following table: 
Table 3. Grade of Students whose Parents have Qualification below SLC/SEE

\begin{tabular}{|c|c|c|c|}
\hline S.N. & Grade & No. of students & Percentage \\
\hline 1 & $\mathrm{~A}^{+}$ & 4 & $8.70 \%$ \\
\hline 2 & $\mathrm{~A}$ & 3 & $6.52 \%$ \\
\hline 3 & $\mathrm{~B}^{+}$ & 5 & $10.87 \%$ \\
\hline 4 & $\mathrm{~B}$ & 2 & $4.35 \%$ \\
\hline 5 & $\mathrm{C}^{+}$ & 4 & $8.70 \%$ \\
\hline 6 & $\mathrm{C}$ & 7 & $15.22 \%$ \\
\hline 7 & $\mathrm{D}^{+}$ & 17 & $36.96 \%$ \\
\hline 8 & $\mathrm{D}$ & 1 & $2.17 \%$ \\
\hline 9 & $\mathrm{E}$ & 3 & $6.52 \%$ \\
\hline & Total & 46 & $100 \%$ \\
\hline
\end{tabular}

Table 3 shows that $4(8.70 \%)$ students obtained $\mathrm{A}^{+}, 3(6.52 \%)$ students obtained $\mathrm{A}$, $5(10.87 \%)$ students obtained $\mathrm{B}^{+}$and $2(4.70 \%)$ students obtained B grade. Similarly $4(8.70 \%)$ students have got $\mathrm{C}^{+}, 7(1.522 \%)$ students obtained C, $17(36.96 \%)$ students obtained $\mathrm{D}^{+}, 1(2,17 \%)$ student obtained $\mathrm{D}$ and $3(6.52 \%)$ students have got $\mathrm{E}$ in $8^{\text {th }}$ grade final examination. The children whose parents have qualification below SLC/SEE have poor achievement in mathematics. Very few students have got $\mathrm{A}$ or $\mathrm{A}^{+}$and large number of students have got $\mathrm{D}^{+}$.

\section{Grade of students whose parents have qualification SLC/SEE}

The achievements of students whose parents have qualification SLC/SEE have been presented in the following table:

Table 4. Grade of Students whose Parents have Qualification SLC/SEE

\begin{tabular}{|c|c|c|c|}
\hline S.N. & Grade & No. of students & Percentage (\%) \\
\hline 1 & $\mathrm{~A}^{+}$ & 10 & 38.46 \\
\hline 2 & $\mathrm{~A}$ & 3 & 11.54 \\
\hline 3 & $\mathrm{~B}^{+}$ & 1 & 3.85 \\
\hline 4 & $\mathrm{~B}$ & 2 & 7.69 \\
\hline 5 & $\mathrm{C}^{+}$ & 3 & 11.54 \\
\hline 6 & $\mathrm{C}$ & 3 & 11.54 \\
\hline 7 & $\mathrm{D}^{+}$ & 4 & 15.38 \\
\hline 8 & $\mathrm{D}$ & - & - \\
\hline 9 & $\mathrm{E}$ & - & 100 \\
\hline
\end{tabular}


Table 4 shows that $10(38.46 \%)$ students obtained $\mathrm{A}^{+}, 3(11.54 \%)$ students obtained $\mathrm{A}$, $1(3.85 \%)$ students obtained $\mathrm{B}^{+}$and $2(7.69 \%)$ students obtained B grade. Similarly $3(11.54 \%)$ students have got $\mathrm{C}^{+}, 3(11.54 \%)$ students obtained $\mathrm{C}, 4(15.38 \%)$ students obtained $\mathrm{D}^{+}$in $8^{\text {th }}$ grade final examination.

\section{Grade of students whose parents have qualification class 12}

The achievements of students whose parents have qualification Class 12 have been presented in the following table:

Table 5. Grade of Students whose Parents' Qualification was Class 12

\begin{tabular}{|c|c|c|c|}
\hline S.N. & Grade & No. of students & Percentage (\%) \\
\hline 1 & $\mathrm{~A}^{+}$ & 4 & 50.00 \\
\hline 2 & $\mathrm{~A}$ & 3 & 37.5 \\
\hline 3 & $\mathrm{~B}^{+}$ & - & - \\
\hline 4 & $\mathrm{~B}$ & 1 & 12.5 \\
\hline 5 & $\mathrm{C}^{+}$ & - & - \\
\hline 6 & $\mathrm{C}$ & - & - \\
\hline 7 & $\mathrm{D}^{+}$ & - & - \\
\hline 8 & $\mathrm{D}$ & - & - \\
\hline 9 & $\mathrm{E}$ & - & $100 \%$ \\
\hline
\end{tabular}

Table 5 shows that $4(50 \%)$ students obtained $\mathrm{A}+, 3(37.5 \%)$ students obtained $\mathrm{A}$, and $1(12.5 \%)$ students obtained $\mathrm{B}^{+}$in $8^{\text {th }}$ grade final examination.

\section{Grade of students whose parents have qualification bachelor degree or above}

The achievement of students whose parents have qualification Bachelor degree or above have been presented in the following table:

Table 6.Grade of Students whose Parents' Qualification was Bachelor Degree or above

\begin{tabular}{|c|c|c|c|}
\hline S.N. & Grade & No. of students & Percentage (\%) \\
\hline 1 & $\mathrm{~A}^{+}$ & 6 & 60.00 \\
\hline 2 & $\mathrm{~A}$ & 3 & 30.00 \\
\hline 3 & $\mathrm{~B}^{+}$ & 1 & 10.00 \\
\hline 4 & $\mathrm{~B}$ & - & - \\
\hline 5 & $\mathrm{C}^{+}$ & - & - \\
\hline 6 & $\mathrm{C}$ & - & - \\
\hline 7 & $\mathrm{D}$ & - & - \\
\hline 8 & $\mathrm{D}$ & - & - \\
\hline 9 & $\mathrm{E}$ & - & - \\
\hline & Total & 10 & $100 \%$ \\
\hline
\end{tabular}


Table 6 shows that $6(60 \%)$ students obtained $\mathrm{A}^{+}, 3(30 \%)$ students obtained $\mathrm{A}$, and $1(10 \%)$ students obtained $\mathrm{B}^{+}$grade in $8^{\text {th }}$ grade final examination. When academic qualification was bachelor degree or more then children achievement was also at least $\mathrm{B}^{+}$or above.

\section{Parents Academic Qualification and Mathematical Achievement in Mathematics}

The academic qualification and mathematical achievement of children has been presented in the following bar diagram:

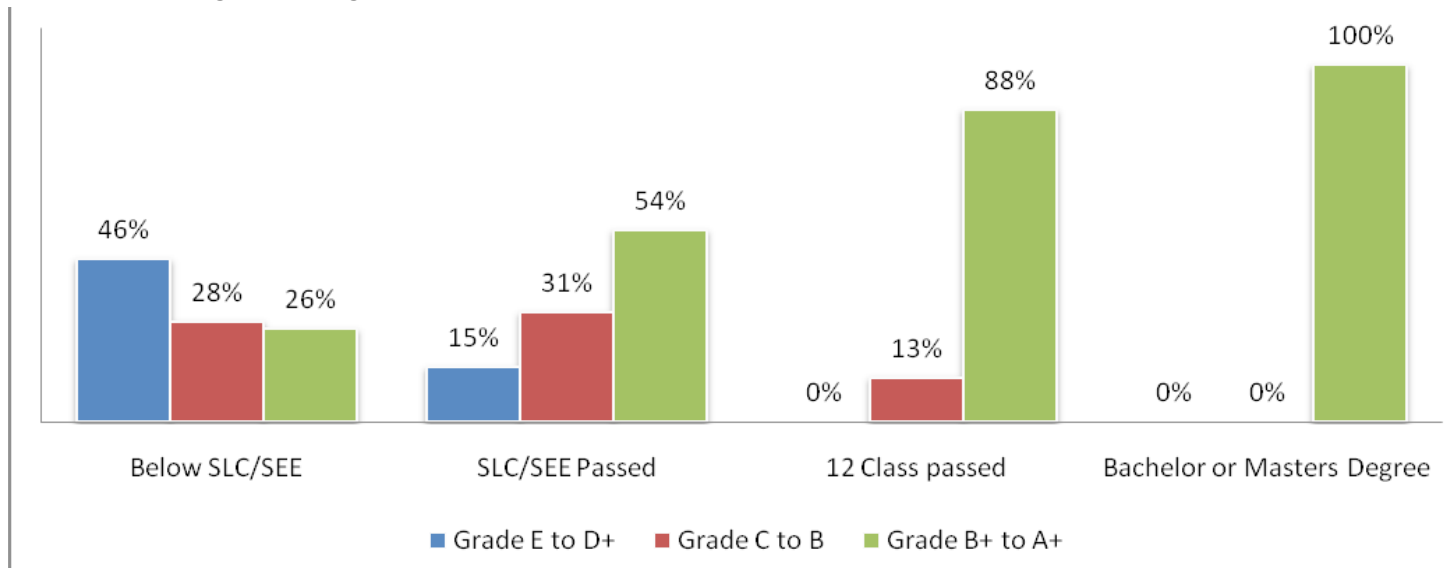

Figure 2. Parents Academic Qualification and Students Grads in Mathematics

Figure 2 shows that academic qualification of parents and achievement of children has positive relationship. When parent's qualification is low achievement of children was also low and when academic qualifications were increase, the achievement also goes up gradually.

\section{Occupation/Profession of Parents}

The occupation/profession of parents has been presented in the following table:

Table 7.Occupation/Profession of Parents

\begin{tabular}{|l|l|c|c|}
\hline S.N. & \multicolumn{1}{|c|}{ Occupation/Profession } & No. of parents & Remarks \\
\hline 1 & Farmers and Masons & 43 & \\
\hline 2 & Business men \& Self employed & 26 & \\
\hline 3 & Working in Organizations & 13 & \\
\hline 4 & Teachers & 8 & \\
\hline \multicolumn{2}{|c|}{ Total } & 90 & \\
\hline
\end{tabular}

We can see from table 7 that large numbers of parents are farmers and masons. Out of 90 parents 43 were farmer and meson, 26 were business men and self employed, 13 were working in government and non-government organizations and 8 were teachers. 


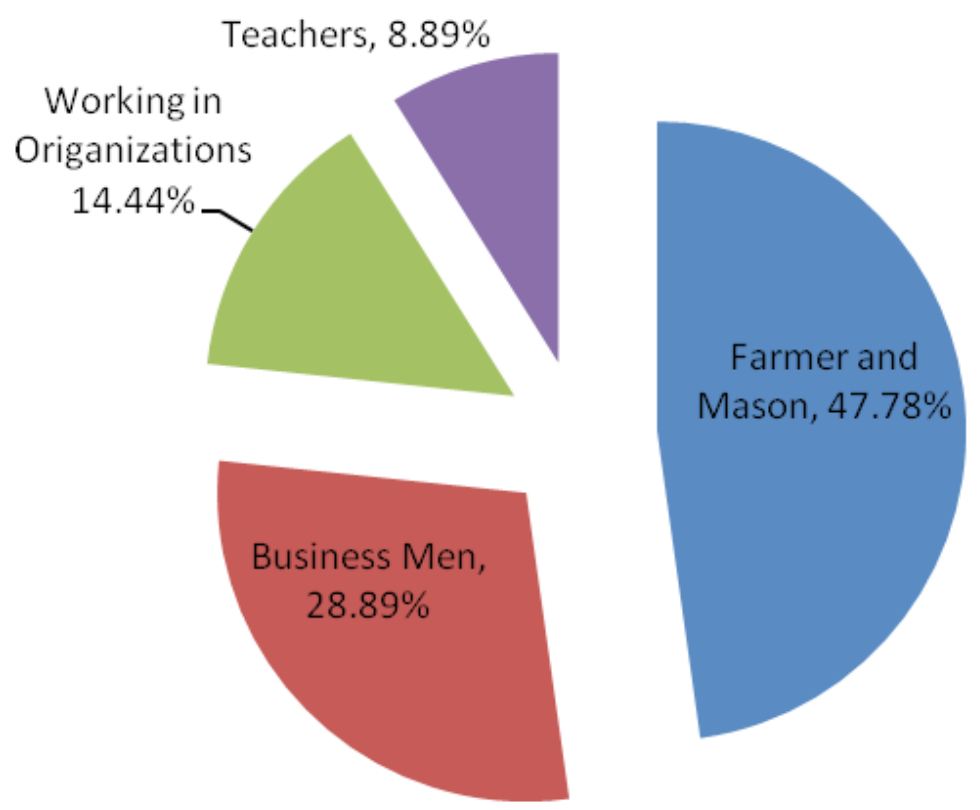

Figure 3. Occupation \& Profession of Parents

From figure 3 we see that 8.89 percent of parents were teachers, 14.14 percents of parents were working in governments and non-government organizations. Similarly 28.89 percent and 47.78 percent of parents were respectively business and farmers \& masons. This shows the majority of people in Sindhuli district were farmer and masons.

\section{Achievement of students whose parents were farmers and masons}

The achievement of students whose parents' occupation/ profession were farming and masons has been shown below:

Table 8. Achievement of Students whose Parents were Farmers and Masons

\begin{tabular}{|c|c|c|c|}
\hline S.N. & Grade & No. of students & Percentage $(\%)$ \\
\hline 1 & $\mathrm{~A}^{+}$ & 3 & 6.98 \\
\hline 2 & $\mathrm{~A}$ & 2 & 4.65 \\
\hline 3 & $\mathrm{~B}^{+}$ & 6 & 13.59 \\
\hline 4 & $\mathrm{~B}$ & 1 & 2.33 \\
\hline 5 & $\mathrm{C}^{+}$ & 5 & 11.63 \\
\hline 6 & $\mathrm{C}$ & 7 & 16.28 \\
\hline 7 & $\mathrm{D}^{+}$ & 15 & 34.88 \\
\hline 8 & $\mathrm{D}$ & 1 & 2.33 \\
\hline 9 & $\mathrm{E}$ & 3 & 6.98 \\
\hline \multicolumn{2}{|c|}{ Total } & 43 & $100 \%$ \\
\hline
\end{tabular}


Table 8 shows that $3(6.98 \%)$ students obtained $\mathrm{A}^{+}, 2(4.65 \%)$ students obtained A, $6(13.59 \%)$ students obtained $\mathrm{B}^{+}$and $1(2.33 \%)$ students obtained B grade. Similarly $5(11.63 \%)$ students have got $\mathrm{C}^{+}$grade, $7(16.28 \%)$ students obtained $\mathrm{C}, 15(34.88 \%)$ students obtained $\mathrm{D}^{+}$ , $1(2,33 \%)$ student obtained $\mathrm{D}$ grade and $3(6.98 \%)$ students have got $\mathrm{E}$ grade in $8^{\text {th }}$ grade final examination. Large number of students whose parents were farmer and masons have got $\mathrm{D}^{+1}$.

\section{Achievement of Students whose Parents were Business men and Self employed}

The achievement of students whose parents' were business men and self employed has been shown below:

Table 9. Achievement of Students whose Parents were Business men and Self-employed

\begin{tabular}{|c|c|c|c|}
\hline S.N. & Grade & No. of students & Percentage (\%) \\
\hline 1 & $\mathrm{~A}^{+}$ & 11 & 42.31 \\
\hline 2 & $\mathrm{~A}$ & 5 & 19.23 \\
\hline 3 & $\mathrm{~B}^{+}$ & - & - \\
\hline 4 & $\mathrm{~B}$ & 3 & 11.54 \\
\hline 5 & $\mathrm{C}^{+}$ & 1 & 3.85 \\
\hline 6 & $\mathrm{C}$ & 2 & 7.69 \\
\hline 7 & $\mathrm{D}^{+}$ & 4 & 15.38 \\
\hline 8 & $\mathrm{D}$ & - & - \\
\hline 9 & $\mathrm{E}$ & - & - \\
\hline & Total & 26 & $100 \%$ \\
\hline
\end{tabular}

Table 9 shows that $11(42.31 \%)$ students obtained $\mathrm{A}^{+}, 5(19.23 \%)$ students obtained A, and $3(11.54 \%)$ students obtained B grade. Similarly $1(3.85 \%)$ students have got $\mathrm{C}^{+}$grade, $2(7.69 \%)$ students obtained C, $4(15.38 \%)$ students obtained $\mathrm{D}^{+}$grade in $8^{\text {th }}$ grade final examination.

\section{Achievement of students whose parents were working organizations}

The achievement of students whose parents' were working in government and nongovernment organizations has been shown below:

Table 10. Grade of Students whose Parents were Working in Organizations

\begin{tabular}{|c|c|c|c|}
\hline S.N. & Grade & No. of students & Percentage (\%) \\
\hline 1 & $\mathrm{~A}^{+}$ & 5 & 38.46 \\
\hline 2 & $\mathrm{~A}$ & 3 & 23.10 \\
\hline 3 & $\mathrm{~B}^{+}$ & 1 & 7.70 \\
\hline 4 & $\mathrm{~B}$ & 1 & 7.70 \\
\hline 5 & $\mathrm{C}^{+}$ & 1 & 7.70 \\
\hline 6 & $\mathrm{C}$ & - & - \\
\hline 7 & $\mathrm{D}^{+}$ & 2 & 15.38 \\
\hline 8 & $\mathrm{D}$ & - & - \\
\hline 9 & $\mathrm{E}$ & - & - \\
\hline & Total & 13 & $100 \%$ \\
\hline
\end{tabular}


Table 10 shows that $5(38.46 \%)$ students obtained the grade $\mathrm{A}^{+}, 3(23.10 \%)$ students obtained A, 1(7.70\%) students obtained $\mathrm{B}^{+}$and $1(7.70 \%)$ students obtained B grade. Similarly $1(7.70 \%)$ students have got $\mathrm{C}^{+}$grade, $2(15.38 \%)$ students have got obtained $\mathrm{D}^{+}$grade in $8^{\text {th }}$ grade final examination.

\section{Achievement of students whose parents were teachers}

The achievement of students whose parents' were teachers has been shown below:

Table 11. Achievement of Students whose Parents were Teachers

\begin{tabular}{|c|c|c|c|}
\hline S.N. & Grade & No. of students & Percentage (\%) \\
\hline 1 & $\mathrm{~A}^{+}$ & 6 & 75.00 \\
\hline 2 & $\mathrm{~A}$ & 2 & 25.00 \\
\hline 3 & $\mathrm{~B}^{+}$ & - & - \\
\hline 4 & $\mathrm{~B}$ & - & - \\
\hline 5 & $\mathrm{C}^{+}$ & - & - \\
\hline 6 & $\mathrm{C}$ & - & - \\
\hline 7 & $\mathrm{D}$ & - & - \\
\hline 8 & $\mathrm{D}$ & - & - \\
\hline 9 & $\mathrm{E}$ & - & - \\
\hline & Total & 8 & $100 \%$ \\
\hline
\end{tabular}

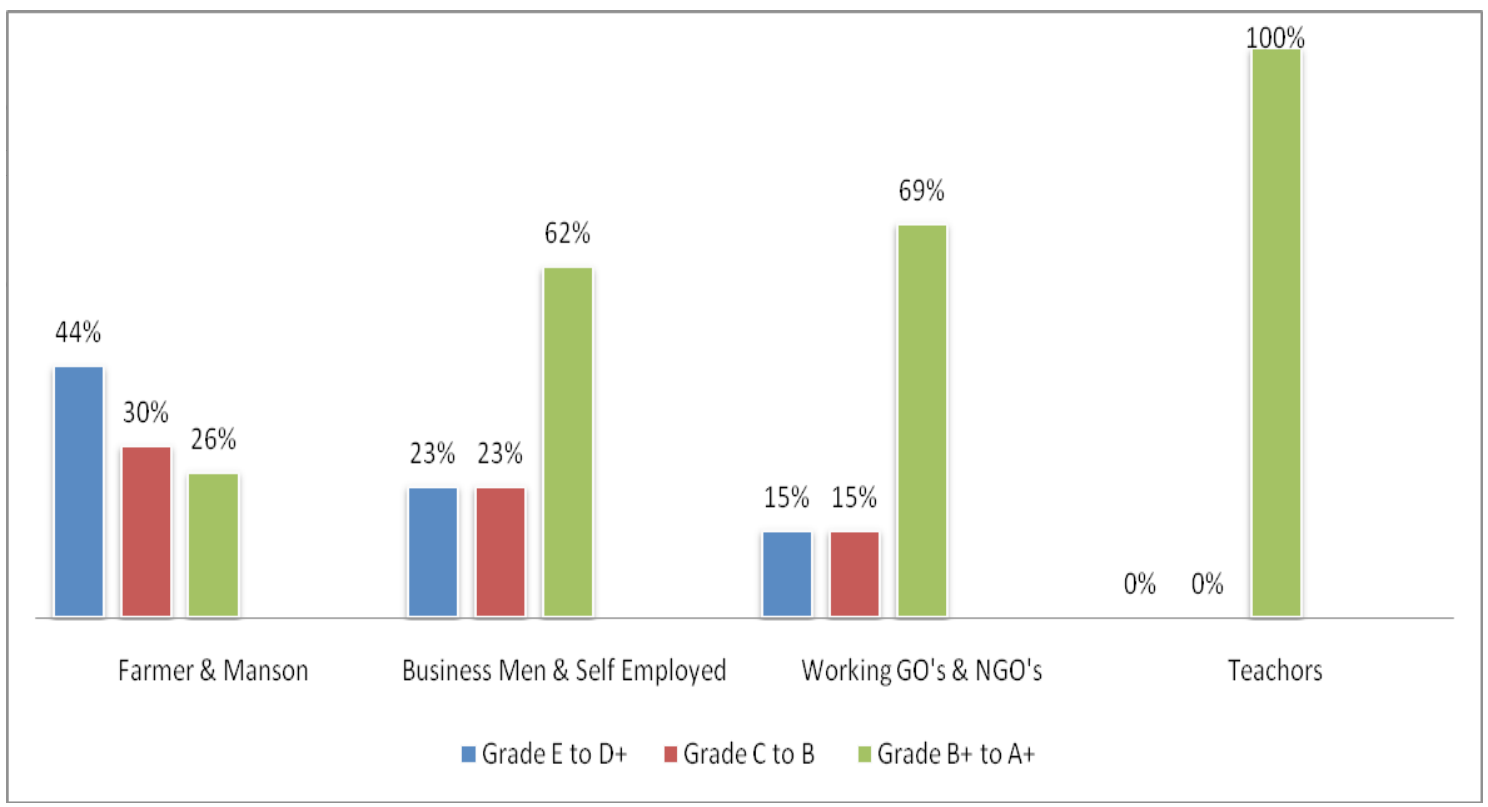

Figure 4. Parents' Occupation/Profession and Achievement of Children 
Parental factors and their effects

Figure 4 shows that mathematical achievement of children depends on occupation of parents. The children whose parents are mason and farmer have poor performance than that of whose parents were business men. Likewise, children whose parents were teacher have better performance than that of working at government and non-government organization.

\section{Monthly Income of Parents}

Monthly income of parents of selected 90 students has been presented in the following table: Table 12. Monthly Income of Parents

\begin{tabular}{|c|l|c|c|}
\hline S.N. & \multicolumn{1}{|c|}{ Monthly Income } & No. of Parents & Percentage (\%) \\
\hline 1 & Below Rs. 30,000 & 56 & 62.22 \\
\hline 2 & Rs.30,000 - Rs.60,000 & 26 & 28.89 \\
\hline 3 & Rs.60,000- Rs.90,000 & 4 & 4.44 \\
\hline 4 & Above Rs.90,000 & 4 & 4.45 \\
\hline \multicolumn{2}{|c|}{ Total } & 90 & 100 \\
\hline
\end{tabular}

Table 12 shows that majority of parents of Sindhuli district have monthly income below Rs.30, 000. Among 90 parents, 56 earn less than Rs.30,000 in a month, 26 earn Rs.30,000 to Rs. 60,000, 4 of them earn Rs60,000 to Rs.90,000 in a month and only 4 of them earn above Rs90,000 in a month.

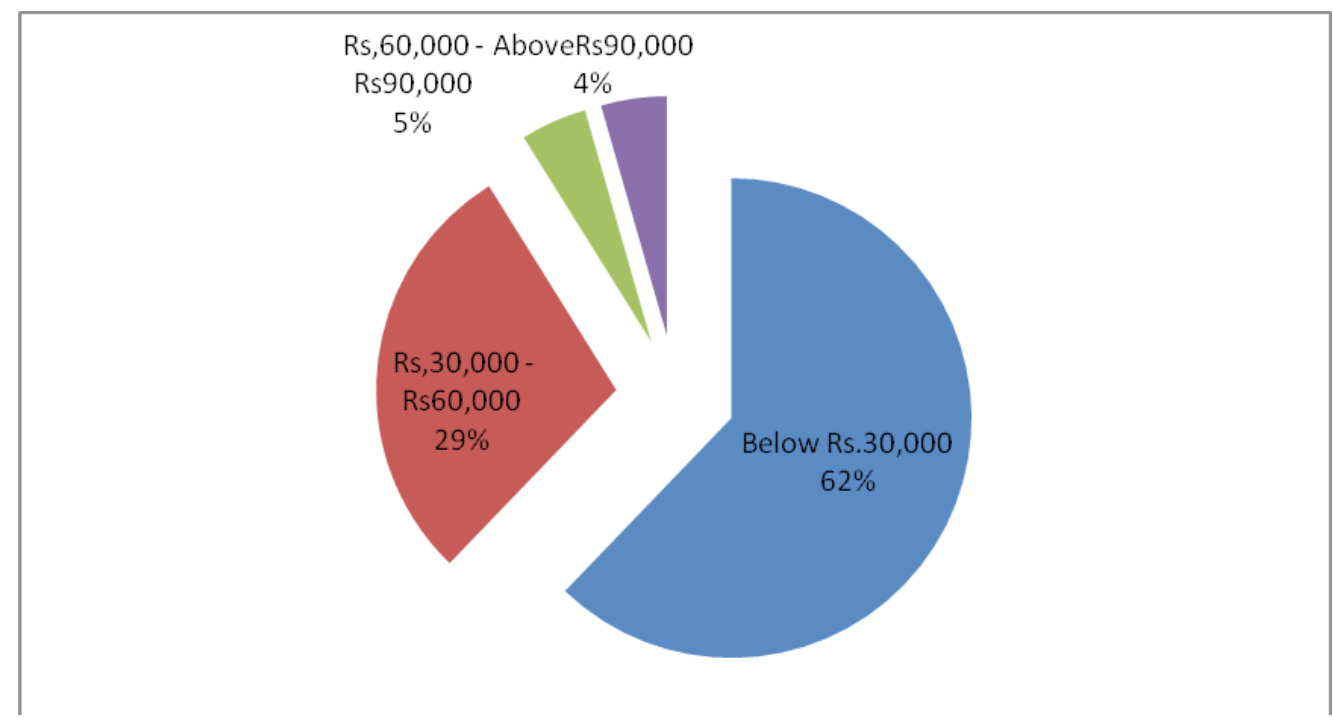

Figure 5.Monthly Income of Parents

Figure 5 shows 62.22 percent parent have monthly income below Rs.30,000, 28.89 percent parent have their between Rs30,000 and Rs60,000, 5 percent parents ' monthly income was between Rs.60,000 to Rs 90,000 and 4 percent parents ' have above income Rs 90,000 per month. This shows that outnumber of parents can expanse less amount of money for their children's education. 


\section{Achievement in Mathematics whose Parents income was less than Rs. 30,000}

Mathematical achievement of students whose parents income were less than Rs30,000 has been presented in the following table:

Table 13. Grade of Students whose Parents' Income was less than Rs. 30,000

\begin{tabular}{|c|c|c|c|}
\hline S.N. & Grade & No. of students & Percentage (\%) \\
\hline 1 & $\mathrm{~A}^{+}$ & 7 & 15.22 \\
\hline 2 & $\mathrm{~A}$ & 7 & 15.22 \\
\hline 3 & $\mathrm{~B}^{+}$ & 6 & 10.71 \\
\hline 4 & $\mathrm{~B}$ & 2 & 3.57 \\
\hline 5 & $\mathrm{C}^{+}$ & 4 & 7.24 \\
\hline 6 & $\mathrm{C}$ & 9 & 16.07 \\
\hline 7 & $\mathrm{D}^{+}$ & 19 & 33.93 \\
\hline 8 & $\mathrm{D}$ & 1 & 1.79 \\
\hline 9 & $\mathrm{E}$ & 1 & 1.79 \\
\hline \multicolumn{2}{|c|}{ Total } & 46 & $100 \%$ \\
\hline
\end{tabular}

Table 13 shows that $7(15.22 \%)$ students obtained the grade $\mathrm{A}^{+}, 7(15.22 \%)$ students obtained A, 6(10.71\%) students obtained $\mathrm{B}^{+}$and 2(3.57\%) students obtained B grade. Similarly, 4(7.24\%) students have got $\mathrm{C}^{+}$grade, 9(16.07\%) students obtained C, 19(33.93\%) students obtained $\mathrm{D}^{+}, 1(1.79 \%)$ student obtained $\mathrm{D}$ grade and $1(1.79 \%)$ students have got $\mathrm{E}$ grade in $8^{\text {th }}$ grade final examination. From this analysis we can say that when economic statuses of parents were low children's achievements were poor.

Achievement of students whose parents' income was Rs.30, 000 to Rs. 60,000

Mathematical achievement of students whose parents' income was between Rs.30, 000 to Rs. 60,000 has been presented in the following table:

Table 14. Grade of Students whose Parents'Income was Rs.30, 000 to Rs. 60,000

\begin{tabular}{|c|c|c|c|}
\hline S.N. & Grade & No. of students & Percentage (\%) \\
\hline 1 & $\mathrm{~A}^{+}$ & 12 & 46.15 \\
\hline 2 & $\mathrm{~A}$ & 4 & 15.38 \\
\hline 3 & $\mathrm{~B}^{+}$ & 1 & 3.85 \\
\hline 4 & $\mathrm{~B}$ & 2 & 7.69 \\
\hline 5 & $\mathrm{C}^{+}$ & 3 & 11.54 \\
\hline 6 & $\mathrm{C}$ & 1 & 3.85 \\
\hline 7 & $\mathrm{D}^{+}$ & 1 & 3.85 \\
\hline 8 & $\mathrm{D}$ & - & - \\
\hline
\end{tabular}




\begin{tabular}{|c|c|c|c|}
\hline 9 & E & 2 & 7.69 \\
\hline \multicolumn{2}{|c|}{ Total } & 26 & $100 \%$ \\
\hline
\end{tabular}

Table 14 shows that $12(46.15 \%)$ students obtained the grade $\mathrm{A}^{+}, 4(15.38 \%)$ students obtained A, 1(3.85\%) students obtained $\mathrm{B}^{+}$and $2(7.69 \%)$ students obtained B grade. Similarly $3(11.54 \%)$ students have got $\mathrm{C}^{+}$grade, $1(3.85 \%)$ students obtained $\mathrm{C}, 1(3.85 \%)$ students obtained $\mathrm{D}^{+}$, and $2(7.69 \%)$ students have got $\mathrm{E}$ grade in $8^{\text {th }}$ grade final examination.

Achievement of students whose parents' income was Rs.60, 000 to Rs. 90,000

Mathematical achievement of students whose parents income was between Rs.60, 000 to Rs. 90,000 has been presented in the following table:

Table 15. Grade of Students whose Parents' Income was Rs.60, 000 to Rs.90,000

\begin{tabular}{|c|c|c|c|}
\hline S.N. & Grade & No. of students & Percentage (\%) \\
\hline 1 & $\mathrm{~A}^{+}$ & 2 & 50.00 \\
\hline 2 & $\mathrm{~A}$ & 1 & 25.00 \\
\hline 3 & $\mathrm{~B}^{+}$ & - & - \\
\hline 4 & $\mathrm{~B}$ & - & - \\
\hline 5 & $\mathrm{C}^{+}$ & - & - \\
\hline 6 & $\mathrm{C}$ & - & - \\
\hline 7 & $\mathrm{D}^{+}$ & 1 & 25.00 \\
\hline 8 & $\mathrm{D}$ & - & - \\
\hline 9 & $\mathrm{E}$ & - & $100 \%$ \\
\hline \multicolumn{2}{|c|}{ Total } & 4 & - \\
\hline
\end{tabular}

Table 15 shows that $2(50 \%)$ students obtained the grade $\mathrm{A}^{+}, 1(25 \%)$ students obtained $\mathrm{A}$, and $1(25 \%)$ students have got obtained $\mathrm{D}^{+}$grade in $8^{\text {th }}$ grade final examination.

\section{Achievement in Mathematics whose parents' income was above Rs. 90,000}

Mathematical achievement of students whose parent's income was above Rs. 90,000 has been presented in the following table:

Table 16. Grade of students whose Parents'Income was above Rs. 90,000

\begin{tabular}{|c|c|c|c|}
\hline S.N. & Grade & No. of students & Percentage (\%) \\
\hline 1 & $\mathrm{~A}^{+}$ & 4 & 100.00 \\
\hline 2 & $\mathrm{~A}$ & - & - \\
\hline 3 & $\mathrm{~B}^{+}$ & - & - \\
\hline 4 & $\mathrm{~B}$ & - & - \\
\hline 5 & $\mathrm{C}^{+}$ & - & - \\
\hline 6 & $\mathrm{C}$ & - & - \\
\hline
\end{tabular}




\begin{tabular}{|c|c|c|c|}
\hline 7 & $\mathrm{D}^{+}$ & - & - \\
\hline 8 & $\mathrm{D}$ & - & - \\
\hline 9 & $\mathrm{E}$ & - & - \\
\hline \multicolumn{2}{r|}{ Total } & $\mathbf{4}$ & $\mathbf{1 0 0 \%}$ \\
\hline
\end{tabular}

Table 16 shows that $4(100 \%)$ students obtained the $\mathrm{A}^{+}$grade in $8^{\text {th }}$ grade final examination. The parents whose income is greater than Rs.90,000 their children obtained $\mathrm{A}^{+}$in final examination 8th grade. This result shows parents whose monthly income greater than Rs.90,000 the mathematical achievement of their children was very good. All the students whose parents have high income have got $\mathrm{A}^{+}$grade in examination.

\section{Economic Status of Parents and Achievement of Children}

The economic status of parents and mathematical achievement of children has been presented in the following figure:

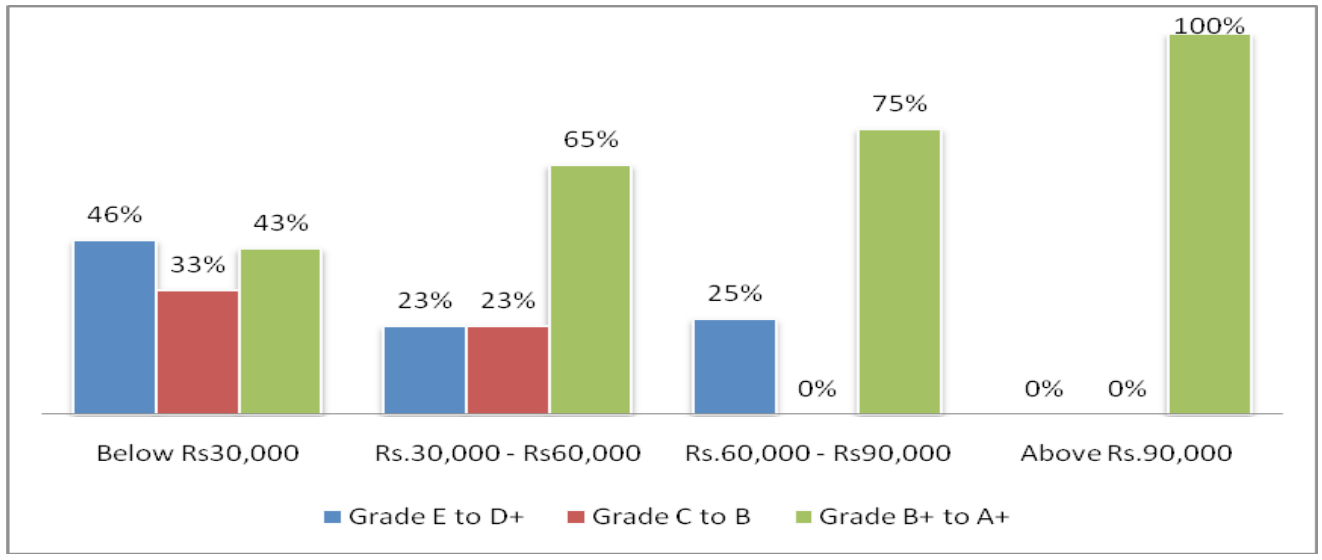

Figure 6. Economic Status of Parents and Achievement of Children

Figure 6 shows that mathematical achievement of children is directly proportional to the income of parents. The children whose parents have income below Rs.30,000 have low achievement than that of whose income is greater than that. Similarly, monthly income of parents was more than Rs.90,000 have got better result than that of whose income were between Rs.60,000 and Rs.90,000.

\section{Test of Hypothesis}

Table 17. Calculation of $\chi^{2} \chi^{2}$ value

\begin{tabular}{|c|c|c|c|c|}
\hline Hypothesis & d.f. & Table value of $\chi^{2} \chi^{2}$ & Cal. Table value of $\chi^{2} \chi^{2}$ & Result \\
\hline I & 6 & 12.592 & 26.15 & Reject $\mathrm{H}_{\mathrm{o}}$ \\
\hline II & 6 & 12.592 & 23.84 & Reject $\mathrm{H}_{\mathrm{o}}$ \\
\hline III & 6 & 12.592 & 13.34 & Reject $\mathrm{H}_{\mathrm{o}}$ \\
\hline
\end{tabular}


Table 17 shows that the calculated and tabulated value of $\chi^{2} \chi^{2}$ at 6 degree of freedom in 5\% level of significance. In hypothesis I, the mathematical achievement of children is not significantly affected by qualification of parents, has the calculated value of $\chi^{2} \chi^{2}=26.15$ is greater than table value of $\chi^{2} \chi^{2}=12.592$. Similarly in hypothesis II, the mathematical achievement of children is not significantly affected by occupation/ profession of parents has the calculated value of $\chi^{2} \chi^{2}=23.34$ is greater than table value of $\chi^{2} \chi^{2}=12.592$ and in hypothesis III, The mathematical achievement of children is not significantly affected by economic status of parents has the calculated value of $\chi^{2} \chi^{2}=13.34$ is greater than table value of $\chi^{2} \chi^{2}=12.592$. Thus we reject all three null hypothesis and except alternative hypothesis. Hence we conclude that there is significance relationship between mathematical achievement and parents' qualification, occupation and economic status in Sindhuli District.

\section{Findings}

From the analysed data it was found that there is significance relationship between parents' education level and children's mathematical achievement. Among parents' qualification, occupation and economic status qualification is most important factor that effect the mathematical achievement of children. A parent's educational attainment is often reflected in the offspring's academic achievement. Highly-educated parents provide more or higher-quality teaching input for their children. Again it was found that there is highly connection between the mathematical achievements of students and occupation of their parents. Students whose patents have been working in government organizations and teacher are working better in mathematics than that of whose parents are farmers and mason.

Also there is remarkable association between the mathematical achievements of students and economic status of their parents. The economic status significantly affects students' performance in mathematics. High economic status of family merely implies the high mathematical achievement. That is, children from high parental economic status obtained better grades in mathematics than those from low parental economic status and they tend to pursue higher educational attainment above secondary school level.

\section{Conclusion and Recommendations}

This study shows that most parents have low academic qualification and poor economic status. Generally parents of the school children in Sindhuli district involving in farming and masons. The conclusion, therefore, was that parental educational level and parents' socioeconomic status affect students academically. Thus, the government and non-governmental organizations should carry out awareness campaign to educate the uneducated parents and convince them about the importance and need of providing their children suitable environment to enhance their educational performance direct and indirect financial asset should provide for the low economic background students like scholarships opportunities as well as through offering of direct financial assistance to homes in order to empower them economically. School management should provide 
suitable environment and lunch special class for needy students from educationally and financially disadvantage family.

\section{References}

Acharya, B. R. (2017). Factors affecting difficulties in learning mathematics by mathematics learners. International Journal of Elementary Education, 6(2), 8-15. Retrieve from: http://www.sciencepublishinggroup.com/j/ijeedu

Ahmad, K., Najeemah B. M.Y.(2013). Influence of Socio-Economic and Educational

Background of Parents on their Children's Education in Nigeria. International Journal of Scientific and Research Publications, 3(10),

Epstein, J. L.( 1991). Effects on student achievement of teachers' practices of parent involvement.

In S.B. Silvern (Ed.). Advances in readings/language research (5th ed., pp. 261-276. Greenwich, CT: JAI Press.

Grissmer, R. H. (2003). Beyond helping with homework: Parents and children doing mathematics at home. Teaching Children at Home, 14,120-131.

Hall, J. F.(1989). Learning and memory (2 ${ }^{\text {nd }}$ edition) Massachusetts: Ally and Bacon.

Herdenson, A.T. (1987). The evidence continue to grow: Parent involvement improves students achievement. Columbia, MD. National Committee for Citizens in Education.

Jeynes, W. H. (2002). Examining the effects of parental absence on the academic achievement of adolescents: The challenge of controlling for family income, Journal of Family and Economic Issues, 23 (2), 189-210.

Musgrave, C. B. (2000). Environmental factors affecting attitude towards science and mathematics. Journal of Educational Psychology 91(1), 382-394.

Pandit, R. P. (1994). Teaching mathematics. Kathmandu, Indira Pandit

Schunk. D. H. Pintrich, P. R. and Mecce J. L. (2008). Motivation in Education: Theory, Research, and Appilication ( $3^{\text {th }}$ edition). Upper Saddle River, New Jersey: Pearson/Merrill Prentice Hall.

Stevenson, D. L., and Baker, D. P.( 1987). The family-school relation and the child's school Performance. Child Development, 58, 1348-1357.

Taiwo, H. G. (1993). Family environment and educational attainment of some school children in Western Nigeria. Journal of Science Teachers Association of Nigeria, 46 (2), 107-116

Young, D.J., Reynolds, A.J.,\& Walberg, H.J. (1996). Science achievement and educational productivity: A hierarchical linear model. The Journal of Educational Research, 89, 272-278

\section{The Author}

Yam Prasad Pandeya is a Lecturer at Siddhajyoti Education Campus Sindhuli, Nepal. He has completed Master's Degree in Mathematics from Tribhuvan University. He has been involving in teaching profession for more than one decade. He is interested in teaching pedagogy and use of modern technology in teaching mathematics. He has carried out a research and published some articles in national 